\title{
Biomechanical strain of goldsmiths
}

\author{
Paula Emanuela Fernandes Cândido a1 , Juliana Vieira Schmidt Teixeira ${ }^{\text {a }}$, Antônio Renato Pereira Moro \\ ${ }^{\mathrm{a}}$ and Leila Amaral Gontijo ${ }^{\mathrm{a}}$. \\ ${ }^{a}$ Federal University of Santa Catarina. Technological Center. Department of Production Engineering and \\ Systems. Coordination of the Post-Graduate Program in Production Engineering. Post Office Box 476 \\ ZIP: 88040-900. Florianópolis, SC, Brazil.
}

\begin{abstract}
The work of the goldsmiths consists in the manufacture of jewelry. The piece, be it an earring, bracelet or necklace, is hand-assembled. This task requires precision, skill, kindness and patience. In this work, we make use of tools such as cuticle clippers and rounded tip, beads or precious stones and also pieces of metal. This type of activity requires a biomechanical stress of hands and wrists. In order to quantify the biomechanical stress, we performed a case study to measure the movements performed by an assembly of pieces of jewelry. As method for research, filming was done during assembly of parts to a paste, using a Nikon digital camera, for 1 (one) hour. The film was edited by Kinovea software, and the task was divided into cycles, each cycle corresponds to a complete object. In one cycle, there are four two movements of supination and pronation movements of the forearm. The cycle lasts approximately sixteen seconds, totaling 1800 cycles in eight hours. Despite the effort required of the wrists, the activity shows no complaints from the employees, but this fact does not mischaracterizes the ability of employees to acquire repetitive strain injuries and work-related musculoskeletal disorders.
\end{abstract}

Keywords: biomechanics, ergonomics, repetitive movements, manual labor.

\footnotetext{
${ }^{1}$ Corresponding author e-mail: paulinhaefc@hotmail.com
} 


\section{Introdution}

The Industrial Revolution was marked by the advent of machines, where a new concept of work emerged, making it more competitive, fast, automated. Since then, each generation technologies become more complete and complex, transforming activity, leading to new demands, establishing new requirements. However, some types of crafts are still important in the production process of some industries. Thus we can say we cannot always replace the activity of man by machine.

The making of jewelry is a hive of activity where technology has not replaced the human being, especially when it comes to the stage of assembling and finishing pieces. These pieces can be pins that need to be finished parts or bases to be adorned.

Depending on the request made by the customer, manufacturers often go largely to eight hours of workday performing this activity, due to the fact that the process is broken down into steps.

Initially they separate all the material that will be used to manufacture the number of parts of the application and then start the installation. The assembly process is done in series, first of all, they bent all the pins to be used for the request and after that will end the piece. In addition to the parts that were used in conjunction with the pin, other elements are used to finish a piece, such as metal rings, chains, and parts for bonding, depending on the type of accessory to be done.

The process is performed manually and with objects considered mild, so that, with daily practice, it becomes faster to handle, and can result in repetitive hand, wrist and forearm. This effort may be consequences to workers' health, causing the Repetitive Strain Injury (RSI) and if the relationship has proven to work, characterized as Work-Related Musculoskeletal Disorders (WRMD) [1].

The aim of this research is to quantify the biomechanical movements performed in the activity of a goldsmith in small business, especially in the assembly of parts of a paste medium, to verify the possibility of this work lead to future injuries to employees.

To do it, we carried out a shooting work with a digital camera, for 1 (one) hour of productive activity. This was divided into cycles, corresponding to an object ready. Within these cycles were divided pronation supination movements of the forearm.

\section{Theoretical foundation}

\subsection{Ergonomics}

The study of ergonomics involves the adaptation of work to the individual, improving their work situation, including their relationships, work system, the behavior acquired and the means of regulation used in work activities. The ergonomic approach aimed at the person, technology and environment, and their relationships $[2 ; 3 ; 4 ; 5]$.

Ergonomics aims to adapt the workplace, machinery, appliances and tools, providing greater comfort and safety in order to reduce the physical effort and mental [6].

It follows three strands: 1) physical ergonomics: anatomical, physiological, anthropometric and biomechanical, 2) cognitive, psychological characteristics, mental processes, the interaction between man and man-man-system, and 3) organizational, organizational systems, its implications, rules and policies. These aspects are interrelated $[3 ; 5]$.

\subsection{Biomechanics}

Biomechanics is the science that studies the physical analysis of the movements of the human body from the point of view of mechanical laws and, in turn, occupational biomechanics "is a part of general biomechanics, which focuses on body movement and related forces work" [5, p. 159]. Thus, considering the human body as a system of mechanical linkages, the various body segments can be measured and located the centers of mass and gravity.

[7], following the line of biomechanics, suggest that RSI/WRMD result from inappropriate interaction of four main biomechanical factors strength, poor posture, upper repeatability and mechanical compression - coupled with insufficient time for tissue recovery.

Activity analyzed in the force required is small, the largest being the repeatability existing problem. The greater the number of repetitive movements performed by the worker in a given time interval, the greater the likelihood of upper limb injuries.

\subsection{Psychosocial and organizational factors}

[8] indicates that in addition to biomechanical factors, the organizational and psychosocial also has 
an outstanding participation in the creation of RSI/WRMD.

The organizational factors are those directly related to the work environment as stress at work (productivity requirements and rhythm), displeasure (not like the activity that executes). As for the psychosocial issues are those related to mental behavior.

\subsection{RSI/WRMD}

According to [7], the functional overuse injuries of the upper limbs are as old as the history of mankind.

The quest for quantity has led workers to make physical and mental effort beyond its limits [9]. This overexertion combined with lack of recovery time can result in Repetitive Strain Injury (RSI) and Work-Related Musculoskeletal Disorders (WRMD). The RSI/WRMD affecting usually the upper limbs. Symptoms may be pain, numbness, heaviness and fatigue, they can be combined or isolated. Risk factors for the onset of RSI / MSDs can be biomechanical, cognitive, sensory, and affective and work organization. These factors should be analyzed concurrently, they are mutually influenced $[9 ; 10]$.

The clinical manifestations of Repetitive Strain Injury (RSI/WRMD) are quite numerous. These can range from well-defined conditions and provide a rapid diagnosis, to chronic pain syndromes caused by multiple factors, often confused with psychological symptoms and several important nonfunctional (paresthesias, headache, tiredness, swelling, difficulty concentrating, etc..) which may impair the diagnosis [7].

Among the various syndromes of RSI/WRMD have the supinator syndrome, occurs when the hypertrophied supinator muscle compresses the posterior interosseous nerve which runs through it. The pronator teres syndrome, which occurs when there is a compression of the median nerve below the elbow, between two branches of the pronator teres muscle. The Carpal Tunnel Syndrome is the compression of the median nerve at the wrist, and the syndrome of the median nerve at the base of the hand, which occurs as a result of extrinsic compression of the nerve, often caused by the use of tools such as screwdrivers cable short and pliers.

\subsection{Manufacture of jewelry}

The making of jewelry is divided into two stages, the first part is performed in the metalworking industry, where the raw parts are produced. The second is due to crafts assembly, crimping, welding and electroplating baths, to make the veneers [10].

The assembly process is performed for the most part, seated, with only upper limb movements. The pieces are light and favor the rapid, repetitive movements, causing an overload in the hands and fingers, and awkward postures or static and inadequate in other parts of the body $[1 ; 10]$.

\section{Materials e methods}

This study was conducted based on the work of a micro-assembly of jewelry, located in São José, Santa Catarina, Brazil.

The work of the goldsmith was shot with a Nikon digital camera for 1 (one) hour. From the footage, we used the software to make Kinovea editing and can count the biomechanical movements performed by the hands, wrists and forearms.

The task was divided into cycles, each cycle represents a complete object. The object in question is a necklace with 200 (two hundred) parts, each of which consists of a bent pin, which is embedded a crystal stone.

We followed the following procedures: a) interviews with people involved in that activity, b) open and systematic observations of work activities, and the main causes of possible injury, c) recording of work activities through videos and photographs, as tool for searching the data collected from observations made "in situ", and d) development and implementation of a questionnaire to employees through open and closed questions, which allowed to diagnose the problems and complaints encountered in performing activities.

With the methodology applied was possible to observe the conditions of work execution on site and assessed their impact on workers' health.

Besides the activity of assembling parts, the goldsmith after completing a full cycle, i.e., when end a piece, are cataloged in this product for enterprise. This activity is performed as follows: it is given a reference number to the product in accordance with existing numerical sequence, completed after a command is shown where the reference number, quantity of pieces, color and 
price. This record is made to the electronics company where it becomes possible to identify how many pieces of each product are in stock. After this activity the employee puts all the pieces on shelves ready for further delivery to customers as requested.

These activities make other positions are held, and another group of muscles are required. Thus the muscles during cooking required more parts can be re-established, which ends up causing the activity does not bring harm to the worker.

\section{Results e discussion}

By analyzing the footage, it was revealed mainly by the effort of forearm, due to the large amount of repetitive movements. Besides this, another factor that makes the activity more tiring and because the activity is always performed by the same hand, i.e., due to the precision required for the activity, automakers cannot switch hands during the performance of activities, use only the hand that has more skill.

For making a medium necklace, are necessary 200 (two hundred) bent pins with a crystal stone, therefore, are conducted 200 (two hundred) cycles with 800 (eight hundred) of supination movements and 400 (four) movements of pronation of the forearm. They are made 3.75 (three point seventy five) cycles per minute, 225 (two hundred and twenty five) cycles per hour and 1800 (one thousand eight hundred) cycles per 8 (eight) hours.

\section{References}

[1] Ribeiro, Herval Pina. Lesões por Esforços Repetitivos (LER): uma doença emblemática. Cad. Saúde Públ., Rio de Janeiro, 13(Supl. 2):85-93, 1997.

[2] Abrahão, Júlia. Reestruturação produtiva e variabilidade do trabalho: uma abordagem da ergonomia. Psicologia: Teoria e Pesquisa, Jan-Abr 2000, Vol. 16 n. 1, pp. 049-05.

[3] Abrahão, Júlia; Sznelwar, Laerte; Silvino, Alexandre; Sarmet, Maurício; Pinho, Diana. Introdução à Ergonomia: da prática à teoria. São Paulo: Blucher, 2009.

[4] Fialho, Francisco A. P.; Santos, Neri dos. Manual de Análise Ergonômica do Trabalho. Curitiba: Gênisis Editora, 1997.

[5] Iida, I.. Ergonomia: Projeto e Produção. 2a Ed. rev e ampl. São Paulo: Blucher, 2005

[6] Souza, N. I. Organização Saudável: Pressupostos Ergonômicos. Tese (Doutorado em Engenharia de Produção) UFSC, Universidade Federal de Santa Catarina, Florianópolis, 2005.
Since the large number of movements made by the wrist joint in a workday, it is possible that the jeweler may trigger health problems like RSI/WRMD as a function of their work activities.

However, for the completion of the piece they need to perform other activities using other muscle groups, which make the activity less painful, since it promotes the home of the muscle groups most affected.

\section{Concluding remarks}

Prevention of RSI/WRMD in the company depends on a set of actions, multidisciplinary, where ergonomics can contribute through the knowledge of human and physical structure of the production process of the company.

According to [11], conduct more effective to prevent RSI/WRMD remains prevention. Character changes ergonomic, organizational and behavioral may reduce or eliminate injuries, and this prevention can reduce the incidence of RSI/WRMD. [9] also show that the invariance of the task monotony physiological and psychological causes.

Although the activity to provide some degree of discomfort and allow the emergence of occupational diseases, the goldsmiths did not have, so far, complaints of symptoms or diagnosis of pathology related to work.
[7] Couto, Hudson Araújo; Nicoletti, Sérgio; Lech, Osvandré Como gerenciar a questão das LER/DORT. Belo Horizonte: Ergo, 1998.

[8] Pereira, Tony Izaguirre; Lech, Osvandré. Prevenindo a LER: Técnicas para evitar a ocorrência de LER. Proteção. Rio Grande do Sul, n 63, p 44-53, março 1997.

[9] Maeno, Maria; Salerno, Vera; Rosi, Daniela Augusta Gonçalves; Fuller, Ricardo. Lesões Por Esforços Repetitivos (LER) Distúrbios Osteomusculares Relacionados ao Trabalho (DORT). Normas e Manuais Técnicos $n^{\circ}$ 103, Ministério da Saúde. Brasil, 2006.

[10]Vilela, Rodolfo Andrade de Gouveia. Ferreira, Marcos Antônio Libardi. Nem tudo brilha na produção de joias de Limeira - SP. Produção, v. 18, n. 1, p. 183-194, Jan./Abr. 2008

[11]Thompson, James S.; PHELPS, Timothy H. Repetitive Strain Injuries: How to deal with "the epidemic of the 1990s". Postigrade-Medicine. USA, v. 88, n8, p 143-149, December 1990. 